\title{
KEMAMPUAN MENULIS TEKS CERITA FANTASI SISWA KELAS VII SMP NEGERI 14 KOTA BENGKULU
}

\author{
Yindri Yahya, Didi Yulistio, dan M. Arifin \\ Program Studi Pendidikan Bahasa Indonesia \\ Jurusan Pendidikan Bahasa dan Seni \\ FKIP Universitas Bengkulu \\ yindriyahya26@gmail.com
}

\begin{abstract}
Abstrak
Tujuan penelitian ini untuk mengetahui kemampuan menulis teks cerita fantasi siswa kelas VII SMP Negeri 14 Kota Bengkulu. Metode yang digunakan dalam penelitian ini adalah metode deskriptif dengan pendekatan kuantitatif. Populasi dalam penelitian ini adalah seluruh siswa kelas VII yang berjumlah 184 orang, sedangkan sampel berjumlah 30 siswa yang diambil secara acak dari populasi. Teknik pengumpulan data yang digunakan yaitu teknik tes menulis teks cerita fantasi kepada siswa kelas VII. Teknik analisis data menggunakan perhitungan rata-rata. Hasil penelitian secara umum menunjukkan bahwa, kemampuan menulis teks cerita fantasi siswa kelas VII SMP Negeri 14 Kota Bengkulu memperoleh skor 76,03 dengan kategori baik.
\end{abstract}

\section{Kata kunci: Kemampuan menulis teks cerita fantasi}

\begin{abstract}
The purpose of this study to determine the ability to write text fantasy story of class VII students in junior school 14 Bengkulu City. The method used in this research is descriptive method with quantitative approach. The population in this study is all students of class VII which amounted to 184 people, while the sample amounted to 30 students taken randomly from the population. Data collection technique used is the technique of writing fantasy story text writing to grade VII students. Data analysis techniques use average calculations. The results of general research indicate that, the ability to write text fantasy story of class VII students in junior school 14 Bengkulu City get score 76.03 with good category.
\end{abstract}

Keywords: Abilities, writing, text, stories, fantasy

\section{PENDAHULUAN}

Pembelajaran Bahasa Indonesia mencakup empat aspek keterampilan berbahasa yaitu keterampilan menyimak, berbicara, membaca, dan menulis. Keempat keterampilan ini sangat erat kaitannya sehingga merupakan kesatuan yang tidak dapat dipisahkan. Keterampilan berbahasa produktif yang harus dikuasai siswa dari tingkat pendidikan dasar hingga perguruan tinggi merupakan keterampilan menulis.

Menurut Tarigan (2003:22), menulis ialah menurunkan atau melukiskan lambang-lambang grafik yang menggambarkan suatu bahasa yang dipahami oleh seseorang, sehingga orang lain dapat membaca lambang-lambang 
grafik tersebut kalau mereka memahami bahasa dan gambaran grafik itu. Aktivitas menulis tidak datang secara otomatis, sehingga membutuhkan kreativitas yang harus dilatih secara terus-menerus karena menulis merupakan suatu kegiatan produktif dalam mengungkapkan pemikiran gagasan dan ide penulis. Akhadiah (1988) menyatakan kemampuan menulis adalah suatu kecakapan untuk menuangkan kalimat-kalimat dalam bentuk tulisan untuk mengekspresikan, menyampaikan, pikiran, gagasan, dan perasaan.

Salah satu tujuan Kurikulum 2013 membentuk dan meningkatkan sumber daya manusia yaitu peserta didik yang produktif, kreatif, inovatif, dan komunikatif dalam proses pembelajaran serta mampu memproduksi beragam jenis teks berdasarkan Kompetensi Dasar (KD) yang dipelajari sesuai dengan Kurikulum 2013. Siswa dijawibkan memproduksi teks pada Kurikulum 2013, dalam hal ini yaitu teks cerita fantasi yang dipelajari siswa kelas VII pada Sekolah Menengah Pertama (SMP).

Pembelajaran berbasis teks bertujuan agar siswa memahami dan mampu menggunakan teks sesuai dengan tujuan serta fungsi sosial teks yang dipelajari. Tahapan yang kompleks dibutuhkan dalam proses pembelajaran berbasis teks. Mulai dari tahap menciptakan prakondisi, tahap pemodelan (percontohan), tahap bekerja sama membangun/mengembangkan teks, dan tahap membangun/mengembangkan teks secara mandiri (Mahsun, 2014:112).

Menurut Nurgiyantoro, (2013:113) cerita fantasi adalah cerita yang menampilkan tokoh, alur, atau tema yang derajat kebenarannya diragukan, baik menyangkut (hampir) seluruh maupun hanya sebagian cerita. Teks cerita fantasi merupakan cerita fiksi yang menghadirkan dunia khayal atau imajinatif yang diciptakan oleh pengarang. Senada dengan hal tersebut menurut Zulela, (2012:47) cerita fantasi adalah cerita yang dikembangkan dengan menghadirkan sebuah dunia lain di samping dunia realitas. Cerita fantasi adalah cerita yang menampilkan tokoh, alur, karakter, dan lainnya yang kebenarannya diragukan, baik seluruh cerita maupun hanya sebagian cerita. Semakin tinggi daya imajinasi dan kreativitas pengarang maka akan semakin menarik teks cerita fantasi yang dihasilkan.

Menulis teks cerita fantasi telah diajarkan guru kepada siswa kelas VII di semester ganjil dalam Kurikulum 2013 yang berbasis teks pada SMP Negeri 14 Kota Bengkulu. Menulis cerita fantasi sangat penting untuk meningkatkan kreativitas dalam mengembangkan imajinasi siswa. Setiap siswa memiliki tingkat imajinasi khayalan yang menarik dan siswa diharapkan mampu mengembangkannya dalam bentuk tulisan teks cerita fantasi sesuai dengan Kompetensi Dasar (KD) dalam Kurikulum 2013. Tujuan pencapaian pembelajaran teks cerita fantasi yang telah dipelajari dalam Kurikulum 2013 terdeskripsi berdasarkan KD 4.4 berisi menyajikan gagasan kreatif dalam bentuk cerita imajinasi secara lisan dan tulis dengan memperhatikan struktur, penggunaan bahasa, atau aspek lisan.

Dari hasil wawancara dengan $\mathrm{lbu}$ Sutatmi, S.Pd. sebagai guru yang mengajar mata pelajaran bahasa Indonesiapada kelas VII di SMP Negeri 14 Kota Bengkulu, bahwa guru merasa siswa mengalami kesulitan dalam mempelajari teks cerita fantasi. (1) Kurangnya minat baca siswa sehingga siswa sulit untuk membedakan menulis teks cerita fantasi dengan teks cerita lainnya menjadi salah satu kendala guru dalam mengajar. (2) Siswa mengalami kesulitan dalam menuangkan ide atau gagasan pada media tulis. (3) Siswa juga kesulitan untuk merangkaikata dan kalimat ketika diminta memproduksi sebuah teks cerita. Sehingga beberapa siswa beranggapan bahwa 
menulis itu suatu kegiatan yang sulit dalam menuangkan ide atau gagasan.

Berdasarkan pemaparan diatas, dapat disimpulkan bahwa pembelajaran bahasa Indonesia mengenai teks cerita fantasi di kelas VII SMP Negeri 14 Kota Bengkulu sangat penting untuk dipelajari dalam mengembangkan gagasan kreatif dalam bentuk cerita imajinasi pada tulisan siswa. Teks cerita fantasi merupakan teks yang baru dimunculkan pada Kurikulum 2013 dalam mata pelajaran Bahasa Indonesia. Berdasarkan hal tersebut, maka peneliti tertarik untuk melakukan penelitian yang berjudul: Kemampuan Menulis Teks Cerita Fantasi Siswa Kelas VII SMP Negeri 14 Kota Bengkulu.

\section{METODE}

Metode penelitian yang digunakan yaitu metode deskriptif dengan pendekatan kuantitatif. Pendekatan kuantitatif pengajaran bahasa dan sastra Indonesia ialah pendekatan penelitian yang menjawab permasalahan-permasalahan pengajaran bahasa dan sastra Indonesia dengan pengukuran terhadap variabelvariabel objek yang diteliti guna menghasilkan simpulan yang dapat digenerasikan, lepas dari konteks waktu dan situasi (Susetyo 2010:6). Teknik tes dapat digunakan untuk mengukur kemampuan dasar dan pencapaian atau prestasi (Arikunto, 2006:223). Dalam penelitian ini, teknik pengumpulan data menggunakan teknik tes menulis yang dilakukan pada siswa kelas VII. Teknik tes digunakan untuk mendapatkan data kemampuan menulis teks cerita fantasi siswa kelas VII SMP Negeri 14 Kota Bengkulu tahun ajaran 2017/2018.

\section{HASIL PENELITIAN DAN PEMBAHASAN} Hasil

Hasil penelitian tentang kemampuan menulis teks cerita fantasi siswa kelas VII SMP Negeri 14 Kota
Bengkulu terdiri dari empat komponen, diantaranya: 1) Kemampuan menulis teks cerita fantasi pada komponen judul, 2) kemampuan menulis teks cerita fantasi pada komponen isi teks, 3) kemampuan menulis teks cerita fantasi pada komponen struktur, 4) kemampuan menulis teks cerita fantasi pada komponen penggunaan bahasa.

1. Kemampuan Menulis Teks Cerita Fantasi Siswa Kelas VII SMP Negeri 14 Kota Bengkulu

Kemampuan menulis teks cerita fantasi siswa kelas VII SMP Negeri 14 Kota Bengkulu mencakup empat komponen penilaian, yakni komponen judul, isi teks, struktur teks, dan penggunaan bahasa. Dari hasil perhitungan, nilai rata-rata diperoleh sebesar 76.03. Dengan demikian, kemampuan menulis teks cerita fantasi siswa kelas VII SMP Negeri 14 Kota Bengkulu mencakup empat komponen berada pada kategori baik atau berada pada rentang skor 70-84.Berdasarkan hasil perhitungantabel dan diagram, diketahui kemampuan menulis teks cerita fantasi siswa kelas VII SMP Negeri 14 Kota Bengkulu terdapat 9 siswa yang menperoleh nilai sangat baik, 11 siswa memperoleh nilai baik, 8 siswa memperoleh nilai cukup, dan 2 siswa memperoleh nilai sangat kurang.

2. Kemampuan Menulis Teks Cerita Fantasi Siswa Kelas VII SMP Negeri 14 Kota Bengkulu pada Komponen Judul

Berdasarkan hasil penelitian mengenai tes kemampuan menulis teks cerita fantasi pada komponen judul yang dilakukan siswa kelas VII di SMP Negeri 14 Kota Bengkulu, diperoleh berdasarkan nilai rata-rata yaitu 7,78 dari kategori penilaian kemampuan menulis pada komponen judul yang disajikan 10 . Jika dimasukkan pada kategori penilaian tersebut, maka kemampuan menulis siswa pada komponen 
judul termasuk dalam kategori baik.Berdasarkan hasil perhitungan tabel dan diagram, diketahui kemampuan menulis teks cerita fantasi siswa kelas VII SMP Negeri 14 Kota Bengkulu dari komponen judul terdapat 9 siswa yang memperoleh nilai sangat baik, 16 siswa memperoleh nilai baik, 4 siswa memperoleh nilai cukup, dan 1 siswa memperoleh nilai sangat kurang.

3. Kemampuan Menulis Teks Cerita Fantasi Siswa Kelas VII SMP Negeri 14 Kota Bengkulu pada Komponen Isi Teks Berdasarkan hasil penelitian mengenai tes kemampuan menulis teks cerita fantasi pada komponen isi teks yang dilakukan siswa kelas VII di SMP Negeri 14 Kota Bengkulu, diperoleh berdasarkan nilai rata-rata yaitu 25.2 dari kategori penilaian kemampuan menulis pada komponen isi teks yang disajikan 30. Jika dimasukkan pada kategori penilaian tersebut, maka kemampuan menulis siswa pada komponen judul termasuk dalam kategori sangat baik.Berdasarkan hasil perhitungan tabel dan diagram, diketahui kemampuan menulis teks cerita fantasi siswa kelas VII SMP Negeri 14 Kota Bengkulu dari komponen isi teks terdapat 19 siswa yang menperoleh nilai sangat baik, 9 siswa memperoleh nilai baik, 1 siswa memperoleh nilai cukup, dan 1 siswa memperoleh nilai kurang.

4. Kemampuan Menulis Teks Cerita Fantasi Siswa Kelas VII SMP Negeri 14 Kota Bengkulu pada Komponen Struktur Teks

Berdasarkan hasil penelitian mengenai tes kemampuan menulis teks cerita fantasi pada komponen struktur teks yang dilakukan siswa kelas VII di SMP Negeri 14 Kota Bengkulu, diperoleh berdasarkan nilai rata-rata yaitu 24.57 dari kategori penilaian kemampuan menulis pada komponen struktur teks yang disajikan 30. Jika dimasukkan pada kategori penilaian tersebut, maka kemampuan menulis siswa pada komponen struktur teks termasuk dalam kategori baik.Berdasarkan hasil perhitungan tabel dan diagram, diketahui kemampuan menulis teks cerita fantasi siswa kelas VII SMP Negeri 14 Kota Bengkulu dari komponen struktur teks terdapat 15 siswa yang memperoleh nilai sangat baik, 11 siswa memperoleh nilai baik, dan 4 siswa memperoleh nilai cukup.

5. Kemampuan Menulis Teks Cerita Fantasi Siswa Kelas VII SMP Negeri 14 Kota Bengkulu pada Komponen Penggunaan Bahasa

Berdasarkan hasil penelitian mengenai tes kemampuan menulis teks cerita fantasi pada komponen penggunaan bahasa yang dilakukan siswa kelas VII di SMP Negeri 14 Kota Bengkulu, diperoleh berdasarkan nilai rata-rata yaitu 18.48 dari kategori penilaian kemampuan menulis pada komponen penggunaan bahasa yang disajikan 30. Jika dimasukkan pada kategori penilaian tersebut, maka kemampuan menulis siswa pada komponen penggunaan bahasa termasuk dalam kategori cukup.Berdasarkan hasil perhitungan tabel dan diagram, diketahui kemampuan menulis teks cerita fantasi siswa kelas VII SMP Negeri 14 Kota Bengkulu dari komponen penggunaan bahasa terdapat 5 siswa yang menperoleh nilai sangat baik, 9 siswa memperoleh nilai baik, 10 siswa memperoleh nilai cukup, dan 6 siswa memperoleh nilai kurang.

\section{Pembahasan}

Berdasarkan hasil penelitian kemampuan menulis teks cerita fantasi siswa kelas VII SMP Negeri 14 Kota Bengkuludiperoleh kategori baik dengan skor 76.03. Kategori baik dapat dikategorikan menjadi sangat baik dengan cara siswa lebih banyak membaca buku yang berkaitan dengan teks cerita fantasi 
dan memperbanyak berlatih kemampuan menulis agar dapat memperkaya kosa kata serta wawasan.

Kebiasaan siswa ketika menulis banyak yang terbiasa tidak memperhatikan penggunaan bahasa, seperti penerapan ejaan, tanda baca, dan huruf kapital. Hal ini terjadi karena siswa masih dalam masa peralihan dari Sekolah Dasar ke Sekolah Menengah Pertama sehingga, siswa masih menerapkan cara penulisan yang belum matang dari Sekolah Dasar terdahulu. Pengetahuan siswa yang masih rendah tentang penggunaan bahasa dapat diperbaiki dengan cara guru selalu memperhatikan dan mengajarkan kembali cara penulisan yang baik dan benar terutama dalam materi menulis teks cerita fantasi pada setiap proses pembelajaran.

Yulistio (2013:99) mengungkapkan menulis merupakan proses menuangkan ide atau gagasan dalam wujud lambanglambang bahasa ortografis dan terstruktur yang dapat dipahami. Senada dengan hal tersebut, Zulela (2012:47) cerita fantasi adalah cerita yang dikembangkan dengan menghadirkan sebuah dunia lain di samping dunia realitas. Cerita fantasi termasuk dalam genre cerita pendek yang pendek (short story). Cerita fantasi adalah suatu karya sastrayang berisi suatu kisah fiksi yang berdasarkan satu peristiwa pokok dari hasil imajinasi pengarang yang derajat kebenarannya diragukan, baik seluruh cerita maupun hanya sebagian cerita.

Pada tahap penulisan tes kemampuan menulis siswa diberikan satu tema yaitu petualangan. Pemberian tema dilakukan agar siswa mudah mengembangkan kreativitas menulis teks cerita fantasi menjadi lebih terarah dan jelas.Kemampuan menulis teks cerita fantasi siswa kelas VII SMP Negeri 14 Kota Bengkuluberada pada kategori baik karena data yang diperoleh telah mengambarkan dengan jelas dan akurat serta telah sesuai dengan teori tentang kemampuan menulis teks cerita fantasi.

Berdasarkan hasil penelitian, komponen yang menempati kategori terbaik dari keempat komponen kemampuan menulis teks cerita fantasi yang diteliti yaitu pada komponen isi teks.Nilai rata-rata yang diperoleh pada komponen isi teks yaitu 25.2 dari kategori penilaian 30 dan termasuk kategori sangat baik. Hal ini dapat dikarenakan siswa telah disediakan fasilitas dengan buku-buku pelajaran bahasa Indonesia yang berkaitan dengat teks cerita fantasi di Perpustakaan sekolah. Sehingga siswa dapat mempelajari isi teks cerita fantasi dengan baik dan dapat menerapkannya dalam sebuah tulisan teks cerita fantasi.

Komponen yang menempati kategori terendah dari keempat komponen kemampuan menulis teks cerita fantasi yang diteliti yaitu pada komponen penggunaan bahasa.Nilai rata-rata yang diperoleh pada komponen penggunaan bahasa yaitu 18.48 dari kategori penilaian 30 dan termasuk kategori cukup. Hal ini terjadi karena sekolah kurang menyediakan fasilitas buku Pedoman Umum Ejaan Bahasa Indonesia Yang Disempurnakan yang memadai diperpustakaan sekolah sehingga siswa tidak mengerti dalam penerapan penulisan penggunaan bahasa yang baik.

Dengan hasil yang diperoleh dari penelitian tersebut, kategori yang dapat dipenuhi siswa secara keseluruhan berada pada kategori baik yaitu skor 76,03 atau berada pada rentang nilai 70-84. Kemampuan menulis teks cerita fantasi dapat mencapai kategori sangat baik, jika siswa memperbanyak latihan kemampuan menulis dan membaca banyak buku yang dapat memperkaya keilmuan pemahaman siswa. 


\section{PENUTUP}

Kesiimpulan

Berdasarkan hasil penelitian dan pembahasan, dapat disimpulkan kemampuan menulis teks cerita fantasi siswa kelas VII SMP Negeri 14 Kota Bengkulu berada pada katerogi baik dengan skor 76.03 atau berada pada rentang nilai 70-84.

Hasil analisis tiap komponen kemampuan menulis teks cerita fantasi siswa kelas VII SMP Negeri 14 Kota Bengkulu yaitu (1) komponen judul, kemampuan menulis teks cerita fantasi pada memperoleh nilai rata-rata 7.78 dengan kategori baik, (2) komponen isi teks, kemampuan menulis teks cerita fantasi pada memperoleh nilai rata-rata 25.2 dengan kategori sangat baik, (3) komponen struktur teks, kemampuan menulis teks cerita fantasi pada memperoleh nilai rata-rata 24.57 dengan kategori baik, (4) komponen penggunaan bahasa, kemampuan menulis teks cerita fantasi pada memperoleh nilai rata-rata 18.48 dengan kategori cukup.

\section{Saran}

Berdasarkan hasil penelitian yang
dilakukan, penulis menyampaikan
beberapa saran yang berkaitan dengan
penelitian ini, sebagai berikut ini.

1. Bagi siswa, diharapkan siswa lebih banyak membaca buku yang berkaitan dengan teks cerita fantasi dan buku yang berkaitan dengan pedoman umum penulisan agar dapat memperkaya kosa kata serta wawasan. Siswa juga diharapkan lebih rajin berlatih kemampuan menulis untuk dapat memperbaiki tulisannya menjadi lebih baik lagi.

2. Bagi guru, diharapkan guru lebih memperbanyak latihan kemampuan menulis siswa dan lebih memperhatikan penggunaan bahasa yang digunakan siswa ketika melatih kemampuan menulisnya.

3. Bagi sekolah, diharapkan sekolah mampu meningkatkan kinerja mengajar guru melalui berbagai pelatihan mengajar sehingga dapat meningkatkan kemampuan menulis teks cerita fantasi yang diajarkan oleh guru kepada siswa di kelas.

\section{DAFTAR PUSTAKA}

Dalman. 2014. Menulis Karya Ilmiah. Jakarta: RajaGrafindo Persada.

Mahsun. 2014. Teks dalam Pembelajaran Bahasa Indonesia Kurikulum 2013. Jakarta: Raja Grafindo Persada.

Nurgiyantoro, Burhan. 2013. Sastra Anak Pengantar Pemahaman Dunia Anak. Yogyakarta: Gajah Mada University Press.

Susetyo. 2010. Penelitian Kuantitatif dan Penelitian Tindakan Kelas. Bengkulu: Universitas Bengkulu.

Tarigan, Henry Guntur. 1994. Menulis Suatu Keterampilan Berbahasa. Bandung: Angkasa.

Yulistio, Didi. 2003. Bahasa Indonesia: Kemampuan Berbahasa Indonesia untuk Mahasiswa di perguruan Tinggi. Bengkulu: Lemlit UNIB Press.

Zulela. 2012. Pembelajaran Bahasa Indonesia. Bandung: Remaja Rosdakarya. 